\title{
JOHN OF SALISBURY AND HIS WORLD'
}

bY CHRISTOPHER BROOKE

\section{(1)}

OHN of Salisbury was born at Old Sarum, somewhere on that windswept hill, about 1115-20. He died on 25 October 1180 in Chartres, and was buried in a finely carved tomb in the abbey church of Notre-Dame-de-Josaphat. ${ }^{2} \mathrm{He}$ was by turns student and scholar, an ecclesiastical administrator and advocate in the Church courts, and eventually a bishop. He enjoyed a fine career associated with noble places-Salisbury, Paris, Canterbury, Rome, Chartres; but outward circumstances at first sight hardly justify his fame. He was also an author of remarkable books and letters: the Policraticus has achieved a modest immortality in two continents at least among the set books for university courses in the history of political thought. ${ }^{3}$ But no serious student of the history of thought has ever, I believe, set John among the immortals: he lived in the century at whose opening Anselm was already old and Abelard learning his elements; as an original thinker, he was not in that class. John's fame is as a mirror of

1 For the recent biographical literature on John of Salisbury, see D. E. Luscombe's paper and bibliography below. Still useful are [C.] Schaarschmidt, Uohannes Saresberiensis (Leipzig, 1862)]; [C. C. J.] Webb, John of Salisbury, (London 1932). See also C. N. L. Brooke in [The] Letters [of John of Salisbur] 1 [ed W. J. Millor, H. E. Butler and C. N. L. Brooke] (London 1955) pp xii-xxiv, and in Letters 2 (Oxford 1979) introduction; the most recent biography is Klaus Guth, Johannes von Salisbury, Münchener Theologische Studien, Hist Abt 20 (St Ottilien 1978). It is generally accepted that he was born in Salisbury on the basis of his name (persistently used by contemporaries), and of his own references to the folk of Salisbury and Wiltshire as gens nostra in the Policraticus viii. 19, 2 371; compare vi. 18, 2 47-8; Webb, John of Salisbury, pp 1-2; and to Salisbury cathedral as mater mea in Letlers 2, 137 (p 16). It would be excessively sceptical to suppose that the surname was only a family name in this case-though it is not wholly impossible-especially as there is some evidence that his family name was parvus (Webb, John of Salisbury, p 1; Letters 2, 212 , pp 342-3).

2 Schaarschmidt p 59; and full references in Letters 2 p xlvii n.; esp to Cartulaire de Notre-Dame de Chartres, ed E. de Lépinois and L. Merlet, 3 vols (Chartres 1862-5) 1, 20. There is a full account of his tomb, with illustrations, by R. Joly and J. Villette in Notre-Dame de Chartres, 2, no 44 (Sept. 1980). pp 10-17.

3 The Policraticus has been made widely known by the translations of bks iv-vi and parts of vii-viii by J. Dickinson (New York 1927), and of bks i-iii and parts of vii-viii by J. B. Pike (Minneapolis 1938); see esp Luscombe below pp $29 f$. 


\section{CHRISTOPHER BROOKE}

his agc: his career reflects so much which was characteristic of the twelfth century, and his writings show a quite exceptional gift for portraying his contemporaries and showing us his world from the inside. As we read his writings we are alternately enthralled by his vignettes of men and events, and shocked by the opportunities he missed. Again and again he litts the curtain, and we turn to ask for a better view; but like the ghost of Hamlet's father he is no longer with us. Today let us be thankful for his gifts and talents, and enjcy them as we can: if he had given us all we might ask for we could hardly contemplate him and his world in the compass of a lecture, or even of a brief symposium.

His value as a mirror of his world is greatly enhanced by two vital elements in his temperament. In his writings he loves to play with complex irony on the two sides of an issue or a person. ${ }^{4}$ Some modern readers have described this as taking an objective view: mercifully it was not quite that, or his comments would be much less interesting and amusing than they often are. It is rather that he enjoyed having the best of both worlds, cutting everybody down to size, while preserving a reasonable respect and sympathy for almost all the men he describes - for he was a man of innumerable friends, with a select, small band of irreconcilable enemies. ${ }^{5}$ The other characteristic was his love of travel: like all compulsive travellers, he can complain of the rigours and difficulties; and it was normal in the 12th century to have a watertight excuse for travelling. When he crossed and recrossed the Alps in the late 1140 s and 1150 s, we may be sure that he always went as the accredited representative of Theobald, archbishop of Canterbury, to the papal curia. ${ }^{6}$ When in his exile in the 1160 s he went from Rheims almost to the mouth of the Rhone and collected the gossip of numerous travellers in those regions, he was officially on a pilgrimage to Saint-Gilles. ${ }^{7}$ But if one contemplates his career at large the impression is inescapable: he accepted commissions which took him over much of Western Europe because he enjoyed it,

4 See esp his treatment of St Bernard and Gilbert de la Porrée in the Historia Pontificalis (cited here from the edition and translation by M. Chibnall (1956) pp $15 \mathrm{f}$ ); or his treatment of Louis IX and his brother the archbishop of Rheims-under whose protection John lived in exile, but of whom he wrote with studied ambiguity-in the later Letters, for example 136, 144, 176 (pp 176-9), 223 etc.

5 Especially Arnulf, bishop of Lisieux: see Letters 1, 17, 18, 30; Historia Pontificalis pp 54-6 etc.

6 See Letters 1 pp xii-xxiv; [A.] Saltman, Theobald (London 1956) esp pp 169-75.

7 Letters 2 pp xix-xx, xxxviii, 552-3, 576-7 (nos. 272, 274). 


\section{John of Salisbury and His World}

enjoyed above all making friends wherever he went. So let us contemplate first of all his work through the places which he knew.

It all began in Salisbury: but of his life and origins here he tells us, alas, almost nothing. He was born under bishop Roger, the great royal servant, the worldly royal chancellor, a type of old corruption as the ardent ascetic and reformer viewed him, who lived in immense splendour in his castles about Wiltshire, with his amazonian concubine Matilda of Ramsbury (if such was her name), and his tribe of sons and nephews, head of one of the great ecclesiastical dynasties of the age. ${ }^{8}$ As we contemplate the tomb of bishop Roger in the cáthedral nave, brought down here from Old Sarum when the cathedral and city were moved in the 13th century, we cannot but regret John's silence about him. ${ }^{9}$ Yet perhaps we can catch the echo of what his comment might have been. If I had to guess who John's father was, I would conjecture that he was a married canon of Old Salisbury under Roger's patronage. ${ }^{10}$ The centre of John's family circle moved in the 1140 s or 1150 s from Salisbury to Exeter, where he and his full brother Richard held canonries, and at least one halfbrother too; and Robert son of Egidia, the half-brother, appears to have been a married canon of Exeter. ${ }^{11}$ Perhaps he was married first and a canon later; but there is little in John's letters to him to suggest anything strange in a priest and canon having a small son ${ }^{12}$-nor anywhere else, in a large body of writings in which innumerable abuses are condemned-to suggest a special rejection of clerical marriage, save evidently for himself. Ecclesiastical historians have too

8 See esp E. J. Kealey, Roger of Salisbury (Berkeley 1972). For the doubt as to Matilda's name, see The Ecclesiastical History of Orderic Vitalis, ed. and trans. M. Chibnall (Oxford, 1968-80), 6, 532-3 nn.

9 For the identification of the tombs and effigies moved from Old Sarum, see [H. de S.] Shortt, ['The three bishops' tombs moved to Salisbury cathedral from Old Sarum'] (Salisbury 1971) repr from Wilts Archaeological and Nat Hist Magazine 57 (Salisbury 1958-60) pp 217-19.

10 It should be emphasised that this is pure conjecture, though it gains a little colour from the fact that his half-brother was the son of 'Egidia', which may suggest a mother not formally married.

11 See Letters 2 pp xxv-xxvi and references, esp to D. W. Blake, 'The Church of Exeter in the Norman Period' (MA thesis, University of Exeter 1970). Letters 2, 147 refers to a nephew, apparently Robert's son, and no 148 to a lady possibly Robert's concubine.

12 Letters 2, 147-8. There are sharp references to incontinent archdeacons in Letters 1, 14-15, 79; but two of these were written in Theobald's name, and all refer to public scandals-furthermore the archdeacon denounced in nos 14-15 was addressed in 2, 253 a few years later in a much more friendly fashion. 
easily picked up the language of eleventh and twelfth century rhetoric, and divided the clergy into good and bad: the good the ascetics, the celibate, the denouncers of women; the bad the worldly, rich, pluralists with their canonries and bishoprics and women. In practice they lived together often, I would judge, in a harmony difficult for the more ardent modern commentator to grasp. ${ }^{13}$ John certainly accepted the other main pillar of Bishop Roger's world: he had in his bones the idea of the career open to talent which would end in canonries and a bishopric: he was certainly a canon of at least two cathedrals in his later years, Exeter and Salisbury: ${ }^{14}$ at Exeter he resided intermittently; at Salisbury, for all we know, hardly at all. As for women, he rarely mentions them; and this I presume to be the tact of the celibate who does not wish to press his condemnation of the accepted way of life of his friends. There is a modest bow in one letter to a lady whom I take to be his sister-in-law. ${ }^{15} \mathrm{When}$ he was an exile for his support to Thomas Becket in the 60s he sent a message to his mother, then living with the family in Exeter ${ }^{16}$ when he returned from exile on 16 November 1170, after an urgent visit to Canterbury and Westminster, 'I speedily made a visit to my mother, who has been ill these two years, and can joyfully await the day of the Lord now that she has seen me; and I earnestly pray she may have a place in the prayers of yourself and the saints who dwell with you (John is writing to his close friend and host in exile, Peter of Celle, abbot of SaintRémi at Rheims). She had received an assurance from the Spirit that she would not see death till she had seen myself and my brother return from exile. ${ }^{17}$ By 2 December we may be sure, and probably some days before, he was back in Canterbury: ${ }^{18}$ it is easier to fit in this speedy visit to his mother if she had returned to Salisbury to die; but we cannot be certain-it is really more probable that he found her among his family in Exeter.

If we know nothing precise of his relations with bishop Roger, we are better informed of his modest, but firm friendship with his

18 Ibid. 2 December was the day of Thomas Becket's arrival in Canterbury: ibid pp 720 1. 


\section{John of Salisbury and His World}

contemporary, Jocelin de Bohun, the other twelfth century bishop whose effigy lies in our midst. ${ }^{19}$ Jocelin came from another great bishop's household, that of Henry of Blois, king Henry l's favourite nephew, king Stephen's brother, bishop of Winchester. ${ }^{20}$ Roger and Henry owed everything to Henry I, and were men of ostentation, splendid patrons, politically ambitious. There the resemblance ended. Henry was that comparative rarity in the English church, a high aristocrat bishop; he was also a monk and celibate. John's attitude to him was deliciously ambivalent. In the 1140 s he had been a bitter rival to John's master Archbishop Theobald for authority in the English Church; and he had been denounced by John's most prestigious early patron, St Bernard of Clairvaux, for undue and unsuitable influence in the disputed election to the archbishopric of York. Bernard, in a heated moment, had referred to Henry in a letter to the Pope, as the 'whore of Winchester'. ${ }^{21}$ John's satirical account of Henry's antics in Rome, and his buying up old statues (he was a notable patron of art), are famous. ${ }^{22}$ But in the late 1160 s Henry became one of the few bishops openly to resist Henry II in his machinations against Becket, and won golden opinions from John. ${ }^{23}$ Jocelin de Bohun was a minor aristocrat who had won patronage and an archdeaconry from Henry. He had gone to Bologna (or anyway to Lombardy) to study law, had an affair (so it seems) with an Italian girl; and his son, Reginald FitzJocelin, also a friend of John's, archdeacon in the Salisbury diocese, later bishop of Bath, nearly archbishop of Canterbury-and immortalised in the exquisite Gothic of Wells cathedral of which he was the first major patron-was known as 'the Lombard' on account of his origin. ${ }^{24}$ In the 1160 s Jocelin fell under Becket's displeasure, and John doggedly faced both ways: Jocelin was one of his bishops, Becket his immediate master. His letters show him

19 On the tomb, see Shortt; on Jocelin, esp. [D.] Knowles, [The] Episcopal Colleagues [of Archbishop Thomas Becket] (Cambridge 1951) pp 17-22, 157 and passim; [The] Letters and Charters of Gilbert Foliot [..., ed. A. Morey and C. N. L. Brooke] (Cambridge 1967) p 538 and refs.

20 On him, see esp Knowles, Episcopal Colleagues, pp 34 seq; Knowles, Monastic Order in England (2 ed Cambridge 1963) pp 287-93; L. Voss, Heinrich von Blois (Berlin 1932).

21 St Bernard of Clairvaux, Epistola 520, in Opera $8 \mathrm{ed} \mathrm{J}$. Leclercq and H. Rochais (Rome 1977) pp 480-2.

22 Historia Pontificalis pp 78-80.

23 Letters 2, 296, pp 682-5.

24 MHTB 3 pp 524-5; compare Knowles, Episcopal Colleagues p 19; A. Morey and C. N. L. Brooke, Gilbert Foliot and his Letters (Cambridge 1965) p 56 and $\mathbf{n}$. 
supporting the archbishop's public thunders while struggling to patch up old friendships behind the scenes. ${ }^{25}$

But we are anticipating. If John's early schooling lay in this neighbourhood, he will always be remembered as one of the brilliant students of the French schools in the late 1130s and 1140s. Every history of Paris and its schools, and of twelfth century learning, has in its core a quotation or a summary or an echo of the famous passage in John's Metalogicon in which he lists the masters at whose feet he sat. He went abroad in 1136 and 'passed about twelve years in varied studies'. ${ }^{26}$ The roll-call is impressive: he came at a crucial time, early enough to hear Abelard's last lectures, late enough to hear a wide variety of other men, Robert Pullen, Robert de Melun, William of Conches, Thierry of Chartres, Gilbert de la Porrée, and many others. ${ }^{27}$ Once again, we are entranced by what he can reveal in quite a few words, infuriated by the gaps. He does not plainly state whether his whole career as a student passed in Paris, or if he wandered, as many did, among the cities of France. This silence has enabled the Abbé Clerval and others to reconstruct a whole school of teachers in Chartres, and to make John a student in a ghost school in the City by which his body undoubtedly lay. ${ }^{28}$ It also gave Sir Richard Southern the occasion for a famous exercise in demolition, in which the school of Chartres was shown to have almost no basis in historical evidence, though its teachers were real men of weight and moment and originality, some of whom may well have taught in Paris. ${ }^{29} \mathrm{I}$ am one of those who found Sir Richard's argument in itself extremely convincing, but still wonder a little if it did not demolish too much. At the very least, can it really be true that so inveterate a traveller as John of Salisbury stayed twelve years in France without studying anywhere but in Paris? It is hard to imagine. However that may be, he sat at the feet of a galaxy of masters; he learned much of philosophy and the whole gamut of the trivium and quadrivium; he studied theology over many years. He laid the foundations of a lifelong enjoyment of rhetoric; his mind was marked by a particular interest in ancient authorities, in philosophic ambiguities, with a love for

25 Letters 2, esp 216-18.

26 Metalogicon ii.10 (ed Webb, Oxford 1929) p 82; compare Letters 1 pp xiv-xv.

27 Metalogicon ii.10, pp 77-83.

28 J. A. Clerval, Les écoles de Chartres au moyen âge (Paris 1895).

29 R. W. Southern, 'Humanism and the School of Chartres', in Medieval Humanism fand other studies] (Oxford 1970) pp 61-85. Compare Letters $2 \mathrm{p} x$ and Luscombe pp 24-5 below. 


\section{John of Salisbury and His World}

finding truth, and falsehood, in both sides of a question, which we have seen was to be the mark of his best ironical prose. ${ }^{30}$

One branch of learning was curiously absent from his early schooling, and that was law. ${ }^{31}$ Curiously, since if John had had to fill in a form between 1147 and 1176 describing his profession, one perfectly good answer might have been: he was a professional lawyer, since he seems to have been on and off through most of the period chief adviser to the archbishop of Canterbury on appeals to the papal curia, and in the early 1170 s adviser on such cases to his close friend, Bishop Bartholomew of Exeter, who was a considerable canonist in his own right. ${ }^{32}$ This is only part of the story; but so far as it goes it seems a well attested fact. The first collection of his letters, mainly covering the years 1156-1161, is one of the most important sources for the history of appeals to Rome from anywhere in Europe in the mid-twelfth century; and one may add that this is not only significant but dramatic, since the mid-twelfth century saw the transformation of the very nature of papal monarchy by the growth of the appeals system. ${ }^{33}$ Yet John has never been very favourably viewed by the professional students of canon law, since his works do not reveal him as a jurist of deep learning, nor has any single gloss on Roman or Canon law been successfully attributed to him. We do not even know how he learned his law; though it is possible that it came after his arrival in Canterbury in 1147, and that he learned it from the Bolognese jurist Master Vacarius whom Theobald imported to ensure that the latest Bolognese fashions were understood in England. ${ }^{34}$ Here is an intriguing puzzle. We should certainly recall that later archbishops were content to use a man of even less legal learning, Master Peter of Blois, as their chief advocate in an important case; ${ }^{35}$ and that it has often happened that the greatest advocates have been men of more eloquence than learning. John was undoubtedly eloquent, a master of rhetoric; an adept diplomat except on the

30 See $n$

31 See Letters 1 pp xix-xxiii; 2 pp xii, xlvi and n.

32 A. Morey, Bartholomew of Exeter (Cambridge 1937); S. Kuttner and E. Rathbone in Traditio 7 (1949-51) p 295.

33 Compare Letters 1 pp xxx-xxxvi.

34 Letters 1 pp xxii-xxiii; on Vacarius see R. W. Southern in Medieval Leaming and Literature: Essays presented to R.W. Hunt (Oxford 1976) pp 257-86; P. Stein in Church and Govemment in the Middle Ages: Essays presented to C. R. Cheney (Cambridge 1976) pp 119-37.

35 Southern, Medieval Humanism pp 107-8; compare Kuttner and Rathbone, Traditio 7 (1949-51) pp 285-6. 


\section{CHRISTOPHER BROOKE}

relatively few occasions when his zeal completely overran his discretion; ${ }^{36}$ a man who made friends everywhere and kept them; an avid traveller. For whatever reason, Theobald sent him again and again to the Curia, almost from the first. When he wrote the Metalogicon in the late 1150 s he could say 'I have been distracted by other tasks, not different merely but inimical to study, so that I could scarcely snatch an hour here and there, and then furtively, to play philosopher. Ten times I have crossed the chain of the Alps since I left England first; twice have I travelled through Apulia; I have done business often in the Roman court on behalf of my superiors and friends; and on a variety of counts I have traversed England, and France too, many times'. ${ }^{37}$

In the course of his years as a student John had won patronage from two leading figures of the monastic world, Peter abbot of Moutier-laCelle, later of Saint-Rémi, a man who vies with Peter the Venerable of Cluny in the charm and urbanity of his letters to a wide circle of which John always remained the centre; and St Bernard himself. ${ }^{38}$ It seems a reasonable guess that John had attracted Bernard's notice as a promising pupil of Bernard's favourite Parisian professor, the English Robert Pullen-like many strong minded men Bernard divided the world, and especially the academic world, into good men and bad; he was as ruthless in promoting the careers of the good as he was in persecuting the bad. He drove Abelard into the arms of Peter the Venerable, but helped Robert Pullen to the dignity of a cardinal; ${ }^{39}$ and he seems to have given John a testimonial which he carried to Canterbury. This was in 1147, and was the first fulcrum upon which John's career rose and fell. ${ }^{40}$ An obscure crisis in the late 1150 s gave

36 As in the case of his negotiations with the Pope on the claims of Henry II to Ireland (compare Letters 1 p 257 and refs) and perhaps Letters 2, 174-5, which may be reckoned to have exacerbated feeling between Becket and the English bishops in the summer of 1166 .

37 Metalogicon iii, prol (ed Webb p 117); compare Letters 1 pp xxiv, 256: we cannot be certain if the figure ten is precisely correct, but any reasonable reconstruction of the nature of John's career in the late $1140 \mathrm{~s}$ and $1150 \mathrm{~s}$ makes it very plausible. On Peter see J. Leclercq, La spiritualité de Pierre de Celle (Paris 1946); Letters 1 pp ix-x and passim. Most of his works are in PL 202; for recent study see G. de Martel in Scriptorium 33 (1979) pp 3-16.

39 F. Courtney, Cardinal Robert Pullen (Rome 1954) cap 1.

40 St Bernard, Epistola 361 (Opera $8 \mathrm{pp}$ 307-8): it is true that Bernard calls him simply John, but the letter is addressed to Theobald; the circumstances fit John of Salisbury and are not known to fit those of any other of Theobald's clerks; and there is some manuscript authority for the address to John of Salisbury in the heading of the letter 


\section{John of Salisbury and His World}

him a period of sabbatical leave to complete his major works, the Metalogicon and the Policraticus, ${ }^{41}$ the even longer period of exile in the 1160 s gave him evidently the chance and impetus to embark on the Historia Pontificalis, an unfinished, semi-satirical, semi-serious essay in history as viewed from the papal curia. ${ }^{42}$ For the rest, he was a man of affairs, and his other major writings, the letters, are mainly concerned with the two preoccupations of the 1150 s and 1160s: with the administration of Theobald's court and appeals cases, and with the struggle between Thomas Becket and Henry II.43

Enough has already been said to reveal the basic theme of this paper. We recall the memory of a man who in a quite extraordinary degree united a local base in England and Salisbury with a cosmopolitan experience characteristic of western Christendom in the twelfth century. Even in exile-perhaps particularly in exile-he revealed himself an Englishman who longed to live in England, anyway for half each year, with a strong sense of loyalty to the people and places from which he sprang; and at the same time a Frenchman, a man of Europe, at home wherever he went. ${ }^{44}$ It is particularly striking how important a source he is, in ways large and small, for the history of the papacy and Italy. Let us look at a few of his throwaway lines. In the late 1150s Peter of Celle dedicated his treatise on Breadfull of biblical learning, largely on the symbolic and tropological significance of bread in scripture-to John; John's letter of thanks runs on the theme: you have filled me with bread, now I want a drink, for I am an Englishman and therefore (notoriously) a toper; and in an extraordinary mixture of joyful conviviality and learned allusion, he

(see Leclercq and Rochais's apparatus, 8 p 307, notes to lines 7-8: they cite one surviving manuscript, their $\mathrm{Rp}$-compare $\mathrm{p} 235$; presumably Mabillon had seen at least one more).

41 See G. Constable in EHR 69 (1954) pp 67-76; Letters 1 pp 257-8.

.42 See Historia Pontificalis, and M. Chibnall below, pp 169-77. The work is anonymous in the only surviving manuscript, and there has been no detailed discussion of its authorship, since its extraordinary congruence with the manner, career and experience of John were first noted-and the authorship attributed to him-by W. Giesebrecht in his Amold von Brescia (Munich 1873) pp 6-7. There are numerous circumstantial points which come readily to hand in favour of his authorship; but it is desirable that the whole case be studied and stated. Mean while, I assume the work to be correctly attributed to John.

43 Letters 1 pp xxv-xxxviii, 2 pp xix-xliv; Saltman, Theobald, passim.

44 The early letters of his exile reveal a strong and continuing desire to return to England; yet many of his letters from Rheims also take for granted that he is at home there-for the phrase 'nos Francos' see Letters 2, 270 pp 546-7. 
compared English beer and French wine, rising to the red wine of the Passion and the white which reflects 'the holiness and cleanliness of chastity' and then switching back to his earlier mood with equal suddenness, placing at the bottom of his list of wines those of the Mediterranean. 'I should prefer any to the wine of Falerno or Palermo or Greece which the chancellor of the king of Sicily used to give me to the peril of my life and my salvation'. ${ }^{45}$ John is an interesting witness on the obscure but important figure of Robert of Selby, chancellor to Roger the Great of Sicily. For Robert's surname, or place of origin, we rely entirely on another English witness, the chronicler John of Hexham. ${ }^{46}$ At one time I supposed that he might have been a fellow citizen of John of Salisbury, for the scribe of the chief manuscript of John of Hexham seems originally to have written an abbreviation mark which would have converted Salebia, Selby, into Saleberia, Salisbury. ${ }^{47}$ But he, or a well-informed colleague, erased the mark and left us guessing, until Martin Brett drew my attention to the reading in the independent manuscript in Paris, which is unambiguously in favour of Yorkshire. None the less, John and Robert link in their different ways the two Norman kingdoms of Sicily and England, and John links them to much in between. Papal affairs apart, John was a witness of a dramatic period in the growth of the Italian cities. Himself a native of a modest northern town-the only ancient hill-fort to be a town in twelfth-century England ${ }^{48}$-he must have felt a certain affinity (such as no Englishman can feel today) in the numerous enchanting hill towns of central Italy. Two rival legends dominate the historiography of Siena, one of the greatest of all hill towns: that of its Roman origin, familiar to visitors to Siena from its adoption in the badge of the wolf of Romulus and Remus, and that of its Gallic origin associated with Brennus duke of the Senones as John calls him; and to the Gallic view John is the earliest surviving witness by several generations. ${ }^{49}$ Of the Roman revolution of Arnold of Brescia, heretic and revolutionary, John is a ever a hill-fort or hill-town in prehistoric times. The ancient hill-towns were
mostly abandoned during the Roman occupation of Britain.

49 Letters 2, 240 pp 456-9 and n. On John and Italy, see R. Manselli, below, 11. 51. 


\section{John of Salisbury and His World}

major source; ${ }^{50}$ but perhaps more remarkable is his place among the contemporary witnesses for the stirring of the Lombard league against Frederick Barbarossa in the 1160s. ${ }^{51}$ In the summer of 1167 the Emperor Frederick Barbarossa sat with a seemingly invincible army at the gates of Rome. The Italian cities, furnished with imperial podestà, lay quiet behind him; pope Alexander III seemed to have been caught in a trap. His very survival, and with him the chances of peace of any kind for Thomas Becket and his supporters, seemed doubtful. But a force more powerful than Frederick intervened; and like Sennacherib from the walls of Jerusalem the emperor was presently in flight, leaving a great part of his army, and several of his chief advisers, dead of the plague. Through the winter of 1167 and 1168 he was a fugitive in north Italy and in the Alps; and the Lombard cities rose, and founded their first League. In December 1167 the League was formed; in the following spring Frederick fled to Germany; early in 1168 the fortress city of Alessandria was founded, witness to this day of the survival of its eponymous hero, pope Alexander. ${ }^{52}$ When I was concerned to annotate the letters referring to this period, I was stupefied to find that of many of these events, especially the details of the emperor's adventures, John is our earliest and even our only witness; and when the citizens of Alessandria and the Lombard league celebrated their centenaries in the late 1960s, in key relazioni Raoul Manselli noted the fact that John's letter of June 1168 was the earliest record of the event. 53 'The Lombards to the emperor's shame (wrote John) are building a city in the fortified town called Roboretum, near Pavia, which they are calling Alessandria in honour of Pope Alexander and to the destruction of the Pavesi' (Frederick's chief remaining allies)-and this is still, in Manselli's words, 'L'indicazione più sintetica e precisa dei vari motivi della fondazione di Alessandria'- 'the most precise and concise statement and interpretation of the various motives for the foundation' of the

50 Historia Pontificalis pp 63-5.

51 Sec T. Reuter below, pp 415f; Letters 2 pp xxxviii-xxxix. For John and the Lombard League see Popolo e Stato in Italia nell'età di Federico Barbarossa, Alessandria e la Lega Lombarda (Turin 1970) esp paper by R. Manselli; see also Manselli in I problemi /della ciniltà comunale) (Atti del Congresso, Bergamo 1967) ed C. D. Fonseca (Bergamo 1971) p 18 and n 50; bibliography in F. Cognasso, Il Piemonte nell'età sveva (Turin 1968) p 843.

52 Letters 2, 272-6, esp (for Barbarossa in the winter of 1167-8) 272, and (for the foundation of Alessandria) no 276, pp 588-9.

53 Sec 1151. 
city. ${ }^{54}$ Of other aspects of the history of the League, especially Henry II's intrigues with it, which have been too often ignored by English historians, John is our only witness. 55

This illustrates his cosmopolitan flavour as well as his importance for the understanding of his world. It is equally important, however, to observe that his witness is neither impeccable nor objective. No historian would go to John for a balanced view of Frederick Barbarossa. ${ }^{56}$ John had first contemplated the Germans across the French frontier; and as he never visited Germany, so far as we know, he had no German friends nor occasion to modify the kind of parthumorous part-rhetorical distaste for German political ambitions and German culture which is the most marked blemish in his cosmopolitan make-up. This antipathy was enlarged by three circumstances. $\mathrm{He}$ was close, even intimate for a time with the English pope Adrian IV; and an ambiguous phrase in one of the letters may well mean that Adrian had hinted an intention to make John a cardinal, prevented by Adrian's early death. ${ }^{57}$ Frederick and Adrian, to state the matter coolly, had not found it easy to meet one another half or any part of the way. Then in 1159, when Adrian died, came the double election to the papacy, and Frederick's support for Victor IV, whom everyone of weight in the English Church came rapidly to assume was the anti-pope. ${ }^{58}$ Finally, when Becket fled from the wrath of Henry II, it was as evident to contemporaries as it is to us that Alexander III's difficulties with Barbarossa (who refused to recognise him as pope) prevented him from whole-hearted condemnation of his own most powerful lay supporter, the English king. ${ }^{59}$ Hence the sharpness of John's anger against the 'Ex-Augustus' as he liked to call him (with no particular justification), which inspired him to imagine a formal papal deposition of the Emperor, an imaginary event which in its turn inspired later historians to enter into the innocuous Lateran synod of 1167 a fictitious account of the deposition which he was supposed to have witnessed. ${ }^{60} \mathrm{John}$ is an important witness to quite

54 Letters 2 pp 588-9; R. Manselli in I problemi (n 51).

5s Letters 2, 290, pp 660-1.

56 See Reuter pp 415-25 below; Letters 1, 124; 2841 (index sv Frederick).

57 Letters 2, 235, pp 434-5; compare 1 p 256.

58 See Mary G. Cheney in EHR 84 (1969) pp 474-97.

59 For all this see T. A. Reuter, 'The Papal Schism, the Empire and the West, 11591169' (DPhil thesis, University of Oxford 1975) and below, pp 417f. See esp Letters 2, 177, 290, pp 182-5, 658-61.

60 For Frederick as 'ex-Augustus' and the Lateran Synod see Letters 2, 242, esp p 474 and $\mathrm{n} 4$. 


\section{John of Salisbury and His World}

distant events in his world; but he is not an objective or always accurate witness. Janet Martin has taught us to look with deep suspicion at some of John's references to ancient authorities-he enjoyed teasing us (to give a generous interpretation) with imaginary sources or faked quotations. ${ }^{61}$ Similarly, there are many points in his letters in which incidents appear to have been invented or distorted; although this is more commonly to be attributed to distortion by rumour, which he may be reporting in all innocence, than to prejudice. Thus he describes a battle in Germany which cannot have taken place (anyway as he describes it), and attributes a sister to the king of Scots-and an improbable plan to marry her in north Italywho appears to be unknown to the historical record and perhaps never existed. ${ }^{62}$ But his love of ambiguity, and the genuine ambiguity of many of his sentiments, often make him a vivid, authentic contemporary witness so long as we always remember that he was never truly detached from the events he describes. ${ }^{63}$ Even the greatest of his enemies, king Henry II, is shown under a dazzling variety of colours: John often refers to him as tyrant, in phrases open or veiled; but equally there are passages of astonishing respect, even reverence; he never doubted that his own future lay in reconciliation to the king, and he tried to have it arranged long before Becket was reconciled. ${ }^{64}$ There are some moments of delicious invective. In the summer of 1166 Gilbert Foliot, bishop of London, Becket's strongest opponent among the bishops of the province of Canterbury, managed to get many of the bishops to put their seals to a letter to pope Alexander in which he defended the king, portraying him as a modest, mild man, astonished by the venom of his old servant the archbishop, just waiting till peace was made before setting off on crusade, in spite of his devotion to wife and children. ${ }^{65}$ Later historians, recalling Henry's violent quarrels with his queen and his sons or his consistent failure to mount his imaginary crusades in the next decade, have found this very hard to swallow. Doubtless we

61 See below pp 179-201; also Janet Martin 'John of Salisbury and the Classics', PhD thesis, Harvard University (1968).

62 Letters 2, 276 pp 588-9, 272 pp 554-5.

63 See $n$ 4. Letters 2, 168 (the account of Becket's thunders at Vézelay in June 1166) and no 304 , with its terrifying account of the events of late November and early December 1170 , are remarkable examples of the vividness with which he can portray contemporary reactions to dramatic events.

64 See esp Letters 2 pp xxiv-xxv and refs.

65 Letters and Charters of Gilbert Foliot, 166;167 sends a similar message to Becket, and is the occasion of John's outbursts (see below). 
have the wisdom of hindsight; John is our witness that contemporaries, even in the 1160 s, tound it sufficiently disingenuous. David Knowles, in a brilliant literary flight, has made it impossible for us to take Gilbert seriously. ${ }^{66}$

'Heaven help us [he is summarising John's rejoinder] what a nerve the man has! "We do not say (John quotes Foliot) that the king has never been at fault, but we do say that he considers it the sweetest of all tasks to listen to those who tell him he is wrong." Does he think that anyone in Europe will swallow this?" And John quotes the resounding climax of Horace's epistle, where the poet tells of the man who, once deceived in the streets by a bogus cripple, refuses to hear even the best authenticated tale of woe; the whole street begs the unfortunate to try his story elsewhere: 'Quaere peregrinum! vicinia rauca reclamat-"Go seek a stranger", the whole neighbourhood howls till it's hoarse'. ${ }^{67}$

Perhaps the most curious feature of this letter is that it was addressed-and taking it all for all, I am convinced that it was sentfrom the security of Rheims into England, to the bishop of Exeter, in whose hands, as a loyal subject of King Henry who had (however reluctantly) set his seal to the bishop's letter, John's epistle must have seemed about as safe a possession as a letter bomb. ${ }^{68}$ One of the many indications, however, that all this invective should not be taken too literally or too seriously, is that it passed, to all appearance, quite freely in and out of Henry's dominions.

So John is not an objective witness to his world; yet he is a vivid, unusual, important witness. And I wish to conclude by sketching the circumstances and contents of two of his most important letters. In doing so I renounce many other possibilities. I could talk of that great treatise of political ideas and all manner of other things, that remarkable and unwieldy fragment of a moral encyclopedia, the Policraticus; I could (if I had the learning) discuss how much we can really learn of the state of philosophical study in John's age from the

66 Knowles, Episcopal Colleagues, p 121; Letters 2, 174 pp 138-41.

67 Horace, Ep i 1762.

68 Letters 2, 174 was addressed to Bartholomew bishop of Exeter; and to Exeter were also addressed several others of his most thunderous epistles. No close student of John's letters has ever believed, I think, that they were literary exercises, not actually sent; the amount of minor gossip in most of them sccms conclusive against this view-and the curious confusion over the addresses of some of the letters to Exeter (noted in Letters $2 \mathrm{p}$ liv) is most readily explained if it reflects the actual condition of the packets of letters sent. 


\section{John of Salisbury and His World}

Metalogicon. ${ }^{69}$ Let me simply say that I have consumed as many years in editing his letters as John spent in writing them, and my friendship with him (not without its ambiguities, as you can imagine) is based upon them. Even from the letters I could follow many intellectual themes, including a revelation of a much deeper biblical learning than he is usually accorded from his famous letter on the canon of scripture to the count of Champagne. But of that, to my pleasure, Professor Saltman writes elsewhere in this book and puts me right; ${ }^{70}$ and there are many more learned in the Policraticus and the Metalogicon than I.

Editing the letters has been one of the toughest tasks of my academic life. At first it was made easy by all that the late Father Millor did in his splendid thesis, and by all that Sir Roger Mynors, and a host of others, had done; ${ }^{71}$ and at all points I was helped by many other scholars. My chief task was to revise H.E. Butler's translation of the early letters and to translate the later ones myself; and to introduce and annotate the whole collection-that is, to explain John's meaning and put it in its setting. The translation was vital to the edition: useless to edit such a collection without really enquiring what it means; impossible to discover what it means unless one tries to express it in one's own tongue. But those kind critics who have helped and castigated my efforts-Roger Mynors, Michael Winterbottom, Diana Greenway-have had to tell me in their various ways that my mind is not up to John's. In some ways I am glad of this: for his mind was immensely complex, subtle, ironical; he loved to write at several levels simultaneously. Even his most forceful rhetoric gets tripped in the complexities of his irony. His more personal letters can be like a labyrinth without a chart. The two I have selected, however, are relatively plain.

In the autumn of 1160 it was clear that archbishop Theobald, John's master, was dying. ${ }^{72}$ His special wish was to see his most brilliant protégé, also his archdeacon, Thomas Becket, before he died;

69 Sec recent studics discussed by D. E. Luscombe pp 22-4, below.

70 Sce pp 21-2, 34-5 below.

71 The edition was based on the London thesis by W. J. Millor, revised by Sir Roger Mynors; the translation to Letters 1 was by H. E. Butler; the whole was revised and annotated (with much help from Millor's thesis), and the translation of Letters 2 provided, by myself, with the help of many scholars named in the preface to 2 , especially Sir Roger Mynors, Dr Michael Winterbottom and Dr Diana Greenway.

72 For what follows sce Letters 1 pp xxxvii-xxxviii, 266-7; M. G. Cheney in EHR 84 (1969) pp 474-97; Saltman, Theobald, pp 54-5. 


\section{CHRISTOPHER BROOKE}

and this wish was very likely sharpened by his own desire to see Becket his successor. Meanwhile Becket was not only archdeacon of Canterbury and nominal head of Theobald's administration; he was also royal chancellor and active head of king Henry II's. This post he had achieved at the very outset of Henry's reign (probably at the beginning of 1155) at Theobald's suggestion. He was the king's inseparable companion in France; and so it was difficult for him to get leave to visit his old master. It has often been said, in imitation of Becket's contemporary biographers, that in 1155 a good cleric was turned into the perfect royal servant, and in 1162 , by a conversion equally dramatic, a worldly, royal servant was converted into an ascetic, intransigeant archbishop $;^{73}$ and although many explanations, some charitable, some very uncharitable, have been found for these transformations, the basic paradox remains. One of John's early letters seems to me among the most significant documents for the whole course of Becket's career. John and Thomas were close personal friends: they had served Theobald together since the 1140s, and in the late 1150s John's two major works were dedicated to the chancellor; in the 1160s John and Thomas were to be exiles in a common cause, even though they lived apart. Thus John to Thomas in the autumn of 1160 :

In accordance with your command, my dear friend, I had drafted my lord's letters to our lord the king and to yourself in such austere terms, that the necessity of your speedy return might be impressed upon you, unless you should prefer to be charged with disobedience and to suffer the penalty of my lord's anathema and the loss of all the possessions which the church of Canterbury has conferred upon you. But since the unexpected arrival of Hugh of Dover with the king's request coupled with promises and cajolements, I have been compelled by the urgent instructions of my lord to temper the rigour of my language and to make some concessions to necessities of state. If the statements of persons returning from overseas are true, as I pray that they may be, the king and all his court are so dependent on your counsel that there is not a hope of peace in the near future, unless your wisdom pave the way for it. This has made my lord to be at times perplexed as to the reason why our lord the king

73 For a recent statement by one of the major authorities, see D. Knowles, Thomas Becket (London 1970); Knowles, [The] Historian and Character, (Cambridge 1963) cap 6. For a less favourable view, [W. L.] Warren, [Henry II] (London 1973), cap 13. 


\section{John of Salisbury and His World}

and yourself from time to time make contradictory demands and give different reasons in your letters for hastening or postponing your return, seeing that common report and rumour seems to indicate that you are so strongly of one heart and mind, that in view of such intimate friendship your desires and dislikes must coincide. He has also sometimes asked whether there may not be some collusion between you in this matter. But I think I have an inkling of the truth, and realise almost as vividly as if I were on the spot what your situation is in the midst of your labours in a distant land. And so when I was compelled to cancel the letters I had already drafted, I began to doubt whether it would not be better to keep back my messenger rather than send him at once. But because he had already received the licence, which we had contrived to get in advance, and was on the point of setting out, I at length decided to explore your feelings; and I have managed to send letters, which I have made as urgent as I could, though they make some concession to the king's will, both to yourself and him. ${ }^{74}$

Thomas was the king's man and the archbishop's man. He was caught in a spider's web of patronage ${ }^{75}$ a kind of trap. The dual authority of the spiritual and the temporal, of king and pope, of church and state, made this a very common kind of trap, and it was frequently to torment John himself. What this letter expresses with unique clarity is Thomas's dilemma throughout his later years: the dual allegiance made him the favourite servant of both his masters, but exposed him to potential suspicion. Theobald was mildly and tolerantly suspicious; Henry was a man of intense, mercurial temperament who could shift in a moment from sunshine to thunder. ${ }^{76}$ Even as chancellor, it was Becket's central problem to convince both his masters that he was still loyal to them; for patronage carries this unavoidable concomitant with it, the need to exhibit loyalty, the fear, on both sides, of the consequences of suspicion of its opposite. When Becket was archbishop, the king

74

75 The nature and significance of this in 12th century England has never been fully explored: for various aspects of it, see esp Southern, Medieval Humanism, cap 11; J. Lally, 'Secular patronage at the court of King Henry II', BIHR 49 (1976) pp 159-84.

76 Warren cap 5, esp pp 207-17, lays out and discusses the contemporary attitudes to Henry II. See also Knowles, Thomas Becket, pp 33-7, 156-9; John's Letters 2, 168, 174 6 (esp pp 156-9), 288. 


\section{CHRISTOPHER BROOKE}

viewed his independence and his stand against the king as mere treachery. ${ }^{77}$ I have no wish to pass judgment now on Becket's manner of stating his independence: no two modern witnesses will ever agree on that $!^{78}$ But it is quite clear that whatever Becket did the long years of ambiguity must make his position intensely difficult; and when the king denounced him as a traitor, proditor ille, a deep feeling of resentment, made harsher by the growing gap between the learned clerk and the secular warrior noble was bound to stir angry and dangerous feelings. On 29 December 1170 these feelings were expressed in a fearful drama in Canterbury cathedral. Soon after, John wrote to his old friend John of Canterbury, bishop of Poitiers, ${ }^{79}$ 'Quite unexpectedly, quite in passing, but by God's mercy, I have just learned that the bearer was on his way across the sea to you', and he seized with pleasure and relief the heaven-sent opportunity to pour out the story of the most famous of his letters. First, he expounded the nature of the deed, then the events of the murder. As the four barons broke into the Cathedral, in the confusion and hubbub, Thomas Becket stood firm, waiting for his end, and with him William FitzStephen and a few others, the more stalwart of his entourage; but most fled, including John himself: let those of us who are convinced we would not have been with him condemn him for it. John's writings reveal a man full of the ordinary human emotions of fear and sensitivity: he was not of heroic mould; yet equally not lacking in moral courage when he saw a principle or a cause clear before him. Thus this letter, though the earliest and one of the most moving, is not an eyewitness account of the murder ${ }^{80}$ But of the aftermath it is. As the murderers left they ordered that the corpse

should not be buried among the holy archbishops, but thrown into a vile marsh or hung on a gibbet. Hence the good men who were there feared that force was being invoked against them, and buried him in the crypt, before the altar of St John the Baptist and St Augustine, apostle of the English, in a marble tomb, before Satan's servants had answered the summons to this sacrilege. And there many mighty wonders are performed, to

77 See esp Knowles, Historian and Character, pp 112-13.

78 See $\mathbf{n} 73$.

79 Lotter: 2,305 . The letter evidently circulated as a narrative of the murder; but there is no reason to doubt that it was originally written as a personal letter to John of Canterbury, bishop of Poitiers, early in 1171.

80 For eyewitnesses, see Knowles, Historian and Character, pp 123-8, and Thomas Becket pp 172-3. For what follows, Letters 2, 305 pp 734-7. 


\section{John of Salisbury and His World}

God's glory: great throngs of people gather to feel in themselves and witness in others the power and mercy of Him who always shows His wonder and His glory in His saints. In the place where Thomas suffered, and where he lay the night through, bcfore the high altar, awaiting burial, and where he was buried at last, the palsied are cured, the blind see, the deaf hear, the dumb speak, the lame walk, folk suffering from fevers are cured, the lepers are cleansed, those possessed of a devil are freed, and the sick are made whole from all manner of disease, blasphemers taken over by the devil are put to confusion: God works all this and more, which would take long to describe; He who alone and over all is blessed for ever, and chose those to be the sharers in His glory whom He meant to cause to triumph over the enemies of truth and faith by true loyalty, zeal for justice, the virtue of confession, and perseverance in steadfastness unconquerable. I should not have dreamt to write such words on any account had not my eyes been witness to the certainty of this.

For some years more John remained in England, carrying on his work at Canterbury, serving his friends the bishops of Worcester and Exeter in handling appeals to the Curia; a dignified elder statesman. ${ }^{81}$ When king and pope had been formally reconciled, and the bishoprics were filled, no bishopric came John's way; and notoriously, it was the king's men, not Becket's clerks, who filled the majority of them. ${ }^{82}$ They included some of John's friends, Reginald son of Jocelin bishop of Salisbury, who became bishop of Bath, and Richard of Ilchester, the great financier, who went to Winchester, in particular. John seemed to have reached the limit of his career, when the noble leader of the French Church, William of the White Hands, bishop of Chartres and archbishop of Sens, suggested to his brother-in-law the Most Christian King Louis that he give up Chartres to their friend and protégé, Master John of Salisbury, in honour of the martyr by whose prayers both hoped to win their way to heaven. ${ }^{83}$ The king and the canons of Chartres acquiesced, and King Henry released him. What Henry really thought I should dearly like to know: perhaps it

81 Sec Latters 2 pp xliv-xlvi.

42 Sce Commeils and Synods, 1, cd D. Whitelock, M. Brett and C. N. L. Brooke (Oxford 1981) pp 956-65; R. Foreville, L'Eglise et la royauté en Angleterre sous Henri II Plantagenêt (Paris 1943), pp 373-84; H. Mayr-Harting in JEH 16 (1965) pp 39-53.

k3 Sec Littors 2 pp xlvi-xlvii; Ralph de Diceto, Opera historica, ed W. Stubbs, RS (1876) 1 pp 410-12. 


\section{CHRISTOPHER BROOKE}

confirmed his suspicions of John's loyalty; in any case it provided a fitting and dignified end to John's career. Hastily putting together the materials he had been collecting (much too slowly) for a magisterial life and letters of St Thomas, he sailed for France, leaving the materials in Canterbury for others to complete.$^{84} \mathrm{He}$ ended his days in Chartres in 1180,800 years ago. But when I contemplate the royal portal-all that is left of the cathedral at Chartres as John knew it-or . when I re-read his letters and hear his familiar voice, it is impossible to believe that he has been parted from us so long. For he lives in his writings as do few of his world.

University of Cambridge

84 Letters 2 pp lviii-lxiii; but see now A. Duggan, Thomas Becket: a Textual History of his Letters (Oxford 1980) esp pp 94-8, and T. Reuter's forthcoming article on John's Life. On John at Chartres, see however Luscombe, pp 35-6 below and references. 